\title{
The Role of Sports Dance in Ensuring the Motor Activity of Students
}

\author{
Iurii Vasiutiak*, Olha Babych, Olena Shoptenko-Ivanova, Anastasiia Zhuravlova, \\ Nataliia Myroniuk, Anzhelika Nebesnyk
}

Department of Choreographic Art, Kyiv National University of Culture and Arts, Kyiv, Ukraine

Received June 28, 2021; Revised July 26, 2021; Accepted September 21, 2021

\section{Cite This Paper in the following Citation Styles}

(a): [1] Iurii Vasiutiak, Olha Babych, Olena Shoptenko-Ivanova, Anastasiia Zhuravlova, Nataliia Myroniuk, Anzhelika Nebesnyk, "The Role of Sports Dance in Ensuring the Motor Activity of Students," International Journal of Human Movement and Sports Sciences, Vol. 9, No. 6, pp. 1299 - 1305, 2021. DOI: 10.13189/saj.2021.090625.

(b): Iurii Vasiutiak, Olha Babych, Olena Shoptenko-Ivanova, Anastasiia Zhuravlova, Nataliia Myroniuk, Anzhelika Nebesnyk (2021). The Role of Sports Dance in Ensuring the Motor Activity of Students. International Journal of Human Movement and Sports Sciences, 9(6), 1299 - 1305. DOI: 10.13189/saj.2021.090625.

Copyright $\bigcirc 2021$ by authors, all rights reserved. Authors agree that this article remains permanently open access under the terms of the Creative Commons Attribution License 4.0 International License

\begin{abstract}
Comprehensive harmonious development of the personality provides adequate physical activity; it is one of the main factors that determine the level of health of young people. Considering students' interests when choosing motor loads increases their motivation for physical culture and health-improving activity in the conditions of sectional work and independent physical exercises. Despite its popularity, sports have become a sport relatively recently, so there is still little research on this topic. The article is devoted to studying influence of sports dance on the provision of students' motor activity. The authors considered the essence and features of sports dance, theoretical and methodological foundations of youth student's motor activity, its principle, identified methods and forms of its control. The theoretical and methodological basis allowed the authors to conduct an experiment during which sports dances replaced one pair of physical education. The authors assessed the influence of sports dance on physical activity, emotional state and physical qualities of students. The experiment showed that the systemic reaction of the body in response to adequate physical activity contributes to its influence on structural and functional restructuring, which is characterized by the appearance of several physiological effects. The results of the experiment showed that sport dance influences the emotional state of students best of all. The authors also gave recommendations on the implementation of sports dance in physical education classes.
\end{abstract}

Keywords Motor Activity, Physical Training, Sport Dance, Students

\section{Introduction}

The reforms carried out in the higher education system have profoundly affected the physical education of student youth $[5,7,9,13]$.

It is known that the comprehensive harmonious development of the individual provides adequate motor activity; it is one of the main factors determining the level of health of young people. It was noticed that students' interests when choosing physical activity increase their motivation for physical culture and health activities in terms of sectional work and independent exercise $[2,3$, 12].

Physical culture classes at the university aim to strengthen students' health and the comprehensive development of the functional capabilities of organs and basic systems of the body [11]. Intensive educational work of students is associated with a reduction in physical activity. By the end of the school day, approximately $80.0 \%$ of students feel a decrease in working capacity, fatigue, sometimes accompanied by headaches, pain in the back and neck muscles, and the muscles of the arms.

Currently, the problem of lack of physical activity of the population is one of the most pressing in the world. Its 
aggravation is due to successes in many fields of science and production. Advances in scientific and technological progress have made modern people's comfortable work and life possible to move quickly over long distances and protect against natural disasters. At the same time, the new "benefits of civilization" have led to the fact that modern youth does not meet the natural genetic need for motor activity, which ensures the constant functioning of responsible systems of human life. The lack of movements characteristic of our time causes disorders of the musculoskeletal system, cardiovascular, respiratory, endocrine, digestive systems, excess body weight, depression, neuropsychiatric disorders, and so on.

One of the main activities aimed at improving the mental performance of students is the constant maintenance of the body in a state of optimal physical fitness. This requirement should be met by such use of physical culture and sports, which contributes to the maintenance of a sufficiently high and stable educational and labour activity of students. Providing this function of physical education is one of the leading in social terms.

Sport today is multifaceted and diverse. Sports dances, despite their popularity, have become part of the sport relatively recently, so there is still little research on this topic. The purpose of the article is to identify whether sport dance as a teaching discipline impacts students.

\section{Sports Dance: Essence, Features}

Sports dancing is a direction that involves the use of movements and elements in an appropriate rhythm and sequence to predetermined music.

Sports dancing is one of the most popular areas: dancing perfectly develops the body and contributes to the harmonious development of the personality while being considered one of the less traumatic sports directions [1, 10].

Over the centuries, the culture of salon dance was formed. Among the dance fans, the best have always stood out, who developed this type of secular entertainment. They became the founders of the first associations, unions, and other dance organizations, which diligently began to systematize knowledge about dancing. This inevitably raised the quality of salon or ballroom dancing and created the basis for dance competitions. The British Association of Teachers of Dancing (B.A.T.D.) is considered the oldest in the world.

At the beginning of the last century, competitions began to be held among dancers performing ballroom dances. Then, to comply with ethical standards, separate competitions were held among dance teachers and separately among their students. Hence, there was a division of competitions into 2 types - competitions for amateurs and professionals.

As time went on, contests rose to a new level and began to be called competitions or tournaments, and sports replaced the name ballroom dance.

Today sports dancing (competitive ballroom dancing) is taught and popular all over the world. They include two main programs: European and Latin American. Each of them involves the performance of five standard dances.

Five "classical" European dances: Viennese Waltz, Slow Waltz, Slow Foxtrot, Quickstep and Tango. In European dances, melody prevails over rhythm.

The Latin American competition program includes five dances: Samba, Rumba, Paso Doble, Cha-cha-cha and Jive. Rhythm is the main thing in these dances.

The types of sports dances are constantly changing and transforming according to the emergence of new musical directions, rhythms, and movements, which is why modern dances are based on fresh, bright melodies, such as strip dance, tectonic breakdance, are more popular now. Strip dance is a mixture of pole dance moves and private dance with sporty elements and classical movements. Strip dance is a real art of seduction based on dance moves. Strip dance classes are held in small groups with the participation of exclusive girls. It is now not stripped plastic that is becoming more and more popular, but the go-go dance, so familiar in clubs. Go-go is fiery rhythms combined with complex movements and active work of the hips. Breakdance is an entirely different direction of dance with complicated tricks that are performed both in a standing position and in a lying position. These types of sports dances have become widespread due to the promotion of the mass of rap culture. Breakdance includes complex, sometimes even acrobatic movements in combination with standard dance plastics and rhythm.

With the introduction of the modern concept of "dancesport", the term "ballroom dancing" began to be reduced to a relatively narrow conception of "sports ballroom dance" or "sports dance".

\section{Theoretical and Methodological Fundamentals of Motor Activity of Student Youth}

In today's world, the health of the population is considered an indicator of the level of development of civilized society. Physical education occupies a special place in human life and formation and is the primary means of organizing motor activity, which from birth determines the basis of its socio-biological existence and development $[4,14,15]$.

Physical education is the only academic discipline in higher education institutions, aimed at attracting students to a healthy lifestyle, forming the general and professional culture of the modern specialist, and improving students' physical and psychophysical condition [6, 8].

Physical education of student youth is a holistic specialized process in which physical development is 
combined with mental education and upbringing. The purpose is to meet the needs of both the individual and society as a whole in the formation of a fully developed person qualified specialist.

Physical activity is an integral part of a person's lifestyle and behaviour. Biological, socio-economic and cultural factors determine it. It depends on the type of occupation, individual psychological, physical and functional characteristics of man, the amount of free time and the nature of its use, the availability of sports facilities and recreation areas, and climatic and geographical conditions.

The importance of physical activity is significantly growing in modern conditions of society, when due to a sharp increase in the complexity of the educational process in general secondary education, the introduction of a multilevel education system in higher education, and mass computerization reduces the physical activity of children, adolescents and young people, especially students of higher education institutions $[3,6]$.

Physical education of students is part of the educational process. One of the urgent problems of physical education of student youth is reliable pedagogical control over determining the level of physical fitness.
There are such types of control in the physical education system as medical, pedagogical control and self-control (Fig. 1).

Depending on the stage of the pedagogical process, the following types of control are distinguished:

1) preliminary - is conducted immediately before training, allows you to assess the initial level of physical condition correctly, physical fitness of students and plan the educational process;

2) current control - is carried out during training, allows you to determine the acquisition of motor skills and adjust further study of the discipline "Physical Education".

3) stage control - is carried out at the end of a particular stage of the study, is used to assess the student's knowledge, skills, and abilities on the topic or section of the course, usually held 2-3 times a semester. The subject of control may be the dynamics of assimilation of new motor action or reaction to the loads that are used to develop a specific physical quality;

4) final control - allows you to assess the student's knowledge, skills, and abilities in the subject as a whole.

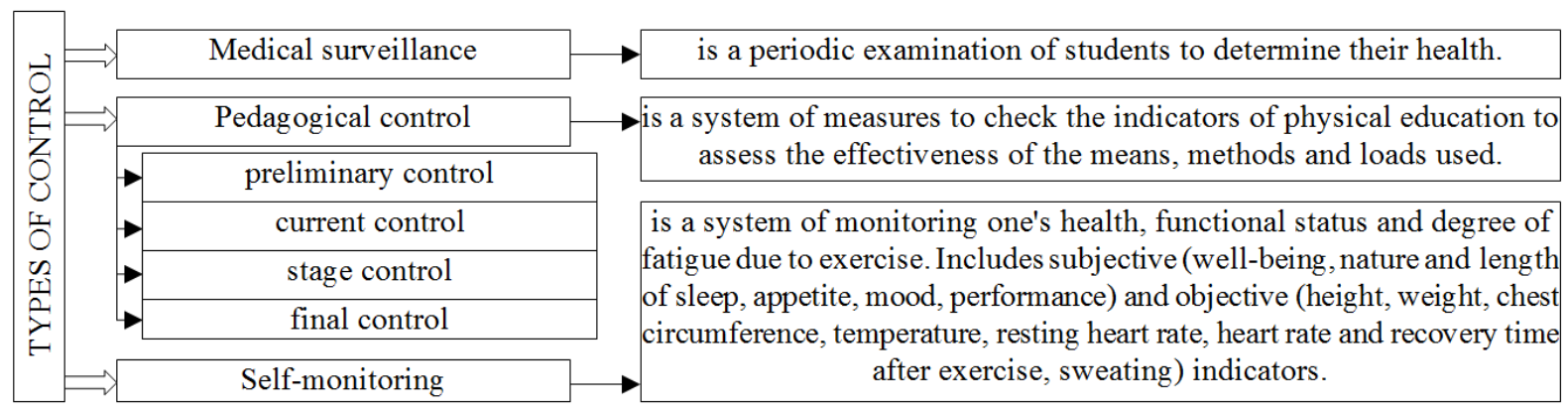

Figure 1. Types of control of physical education 
The main component of the content of the motor activity, regardless of its goals, is the observance of basic principles (Fig. 2).

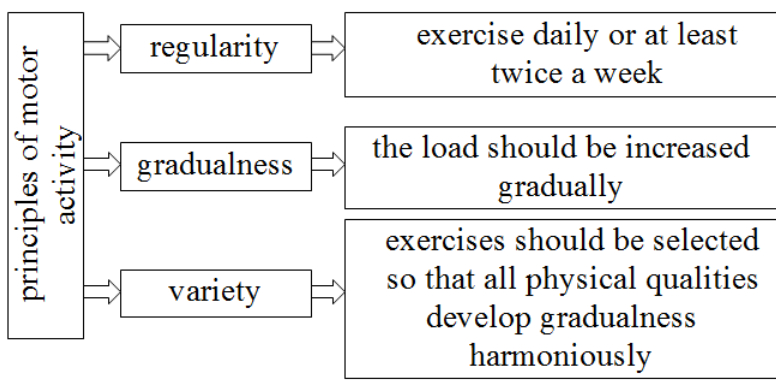

Figure 2. Principles of motor activity

According to scientists J. Wilmore, D. Costill, it can be argued that the amount of physical activity depends on physical fitness. The individual norm of motor activity is determined by achieving a specific physical condition, which can be expressed by quantitative indicators of physical performance, physical fitness, and the functional state of the body's essential systems [17].

The energy fund and the functional state of organs and systems at different age stages depend on the functioning of skeletal muscles. In this case, the more intense the motor activity within the optimal, the more the main non-entropic factors are manifested, which increase energy resources, functionality and life expectancy of the organism $[13,16]$.

\section{Sport dance in Providing Motor Activity of Students: Experiment}

We consider it very important to assess the influence of various factors not only on motor activity, i.e. impact on the physical component but also on the moral one.

The experiment was carried out at the Kyiv National University of Culture and Arts. For two semesters. In the control group, physical culture lessons were conducted as usual; in the experimental group - one class per week was replaced by sports dancing throughout the semester.

We will evaluate the influence of sports dance in ensuring the motor activity of students by such indicators (Table 1).
Table 1. Effects of motor activity of the body system

\begin{tabular}{|c|c|}
\hline System & The nature of the changes \\
\hline $\begin{array}{c}\text { Cardiovascular } \\
\text { system }\end{array}$ & $\begin{array}{l}\text { decreased heart rate at rest and during standard } \\
\text { exercise; myocardial contractility (heart } \\
\text { muscle) improves; the heart muscle's need for } \\
\text { oxygen decreases; increases productivity, heart } \\
\text { reserves; increases the elasticity of blood } \\
\text { vessels; their lumen increases; blood pressure is } \\
\text { normalized. }\end{array}$ \\
\hline $\begin{array}{l}\text { Respiratory } \\
\text { system }\end{array}$ & $\begin{array}{l}\text { respiratory muscles develop, their strength } \\
\text { grows; the total capacity of lungs increases; } \\
\text { there is a physiologically appropriate } \\
\text { development of the capillary network of the } \\
\text { lungs; improves the efficiency of respiratory } \\
\text { function; the reserves of the respiratory system } \\
\text { increase. }\end{array}$ \\
\hline $\begin{array}{l}\text { Musculoskeletal } \\
\text { system }\end{array}$ & $\begin{array}{l}\text { improves the blood supply and nervous } \\
\text { regulation in the muscles, increases the activity } \\
\text { of enzymes that accelerate aerobic (oxygen) and } \\
\text { anaerobic (oxygen-free) reactions in the } \\
\text { muscles; muscle elasticity and ligaments } \\
\text { improve; joint mobility improves. }\end{array}$ \\
\hline Nervous System & $\begin{array}{l}\text { increases mobility and increases the balance of } \\
\text { nervous processes; reduced sensitivity to stress. }\end{array}$ \\
\hline
\end{tabular}

The emotional state was assessed through subjective well-being and level of anxiety (Table 2).

The dynamics of physical qualities were also assessed: flexibility, coordination abilities, strength, endurance and speed.

The grades were obtained by self-analysis and averaging indicators for two semesters (Fig. 3).

The table shows that the most significant sports dance positively affected the emotional state; therefore, we present the results more detail (Fig. 4-5).

Table 2. Criteria for assessing the emotional state

\begin{tabular}{|c|c|}
\hline Condition & The severity of the condition \\
\hline \multirow{4}{*}{$\begin{array}{c}\text { Subjective } \\
\text { well-being scale }\end{array}$} & complete emotional well-being \\
\cline { 2 - 2 } & deviation towards subjective well-being \\
\cline { 2 - 2 } & moderate subjective well-being \\
\cline { 2 - 2 } & deviation towards subjective trouble \\
\hline \multirow{4}{*}{ Alarm scale } & pronounced emotional discomfort \\
\cline { 2 - 2 } & medium (with a tendency to low) \\
\cline { 2 - 2 } & medium (with a tendency to high) \\
\cline { 2 - 2 } & high \\
\cline { 2 - 2 } & very high \\
\hline
\end{tabular}




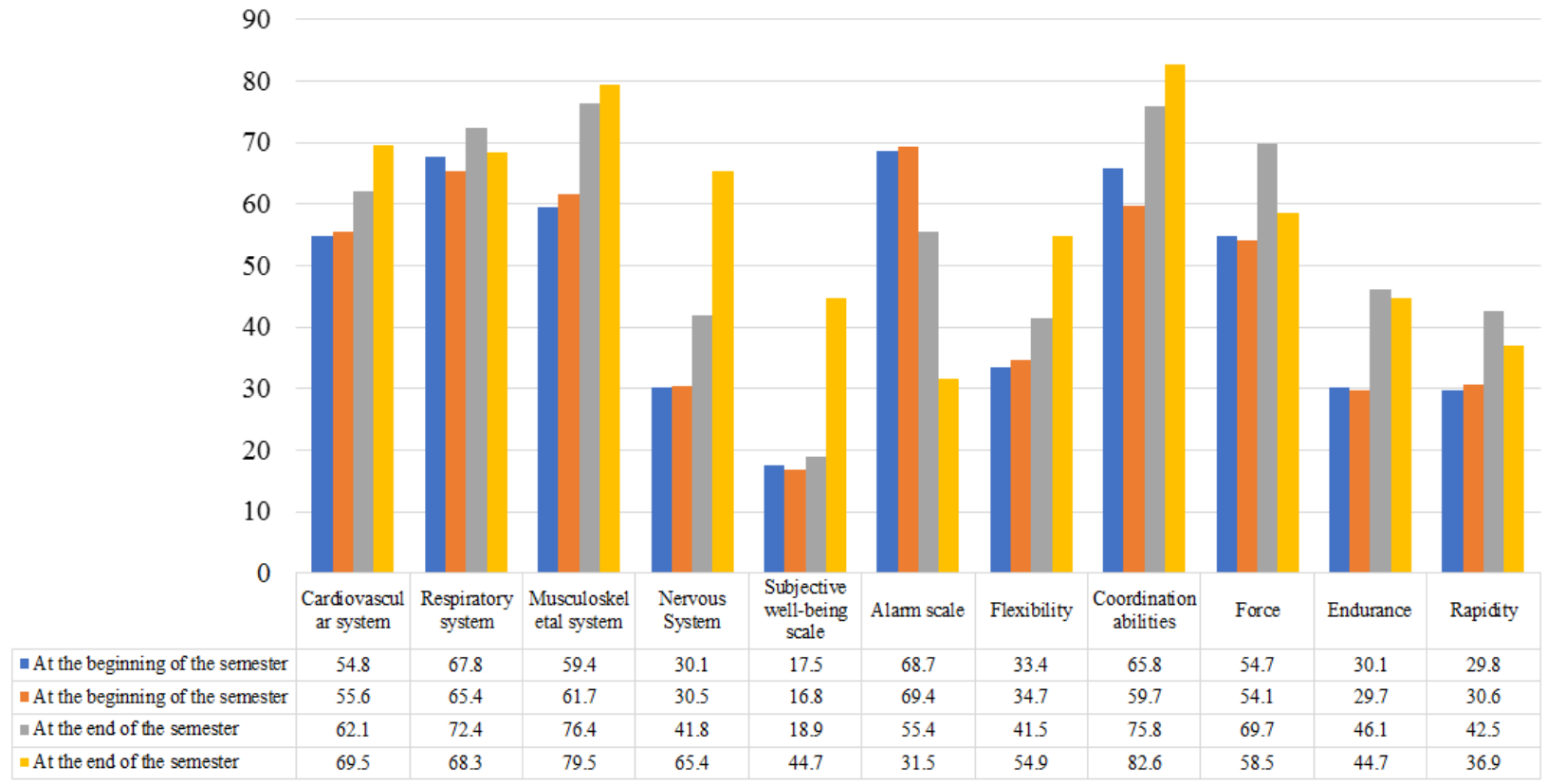

Figure 3. The results of the influence of sports dance on motor activity, emotional state and physical qualities of students for 2018-2020

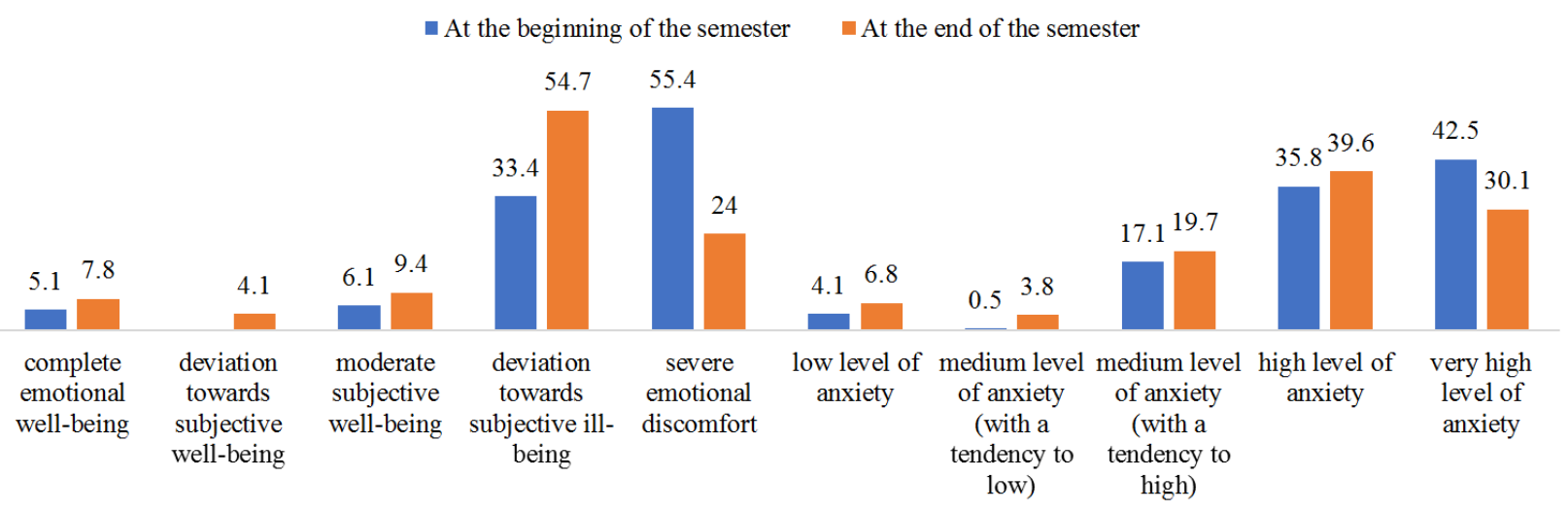

Figure 4. The results of the influence of sports dance on the emotional state of students for 2018-2020 (control group)

- At the beginning of the semester $\quad$ At the end of the semester

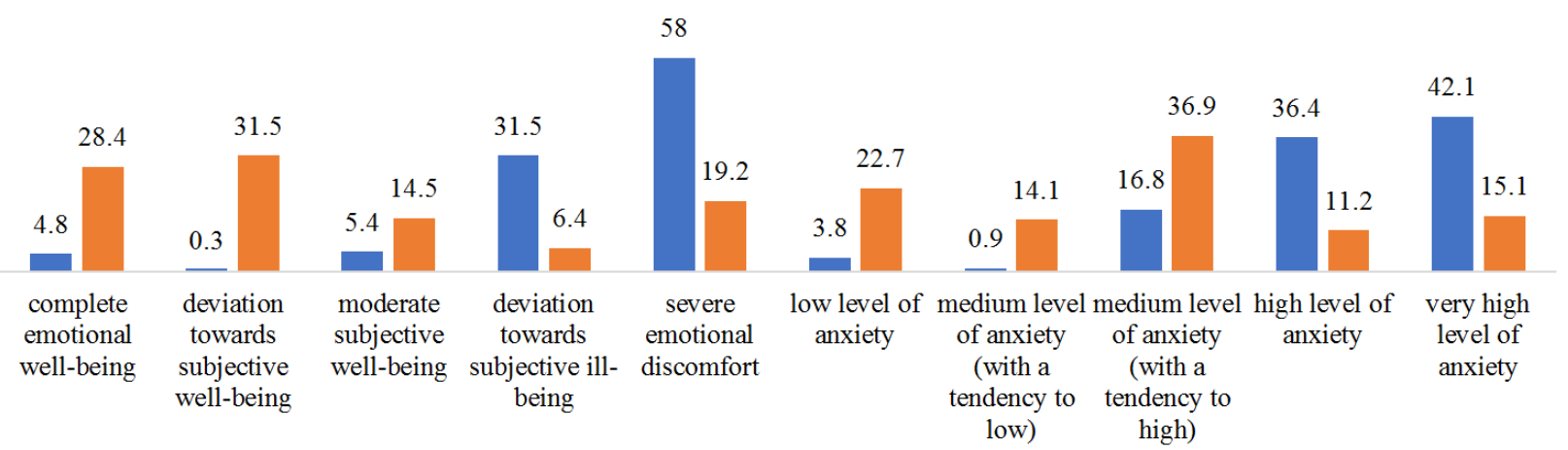

Figure 5. The results of the influence of sports dance on the emotional state of students for 2018-2020 (experimental group) 
The following conclusions can be drawn from this experiment:

- sports dances are an excellent addition to the physical activity of students;

- sports dances have the best effect on the emotional state of students: they increase subjective well-being by $27.9 \%$ and reduce anxiety by $37.9 \%$;

- sports dances should be used precisely as an addition to the main physical activity because such loads as running, jumping, exercises give more significant results in the development of strength (by 10.4\%), speed (by $6.7 \%$ ).

- the ideal ratio of sports dance to physical activity is 1: 3 , i.e. half a pair (45 minutes) - sports dances and one and a half pairs ( 1.5 hours +45 minutes) physical education.

The organism's systemic reaction in response to adequate physical activity contributes to its influence on the structural and functional adjustment, which is characterized by the appearance of several physiological effects. Among them is the increase of nonspecific resistance, compensatory and protective-adaptive possibilities, the economization of physiological functions at rest, and the dosed physical activity. In addition, sport dance has a significant emotional impact on the condition of students.

\section{Conclusions}

Physical activity is a natural requirement for the harmonious development of the human body. If a person in childhood is limited in the natural need to move, then his natural mental and physical inclinations will not receive the proper progressive development. Restriction of physical activity leads to functional and morphological changes in the body, a decrease in a person's mental and physical performance. Of particular importance are the harmonization of motor activity and the professional development of a young person during the period of higher education. Thus, contradictions arise between the increased need to intensify the mental work of students in the modern educational space and the insufficient motor activity of young people in the process of studying at a university as a necessary condition for strengthening and maintaining health.

Sport dancing is a complex coordination sport, which is a symbiosis of art and sport. After their recognition as a sport, there were several areas for the use of sport dances in the field of physical culture and sports. One of such areas is the introduction of elements of dance training in physical education programs in educational institutions of various types, including free economic zones. Research has shown that the introduction of sports dance elements in students' physical activity can increase their motor activity and improve their physical and emotional state.

\section{REFERENCES}

[1] Banio A., "Sports Dance and the Process of Socialization," Central European Journal of Sport Sciences and Medicine, Vol. 9, pp. 85-90, 2015. DOI: 10.18276/cej

[2] Bondar I., Humenchuk A., Horban Y., Honchar L., Koshelieva O., "Conceptual and Innovative Approaches of Higher Education Institutions (Heis) to the Model of Training A Successful Specialist Formation During a Covid Pandemic, " Journal of Management Information and Decision Sciences, Vol. 24, No. 3, pp. 1-8, 2021.

[3] Bondar I., Humeniuk T., Batchenko L., Horban Y., Honchar L., "State Regulation of the Development of Educational and Scientific Process in Higer Education Institutions," Journal of Management Information and Decision Science, Vol. 24, No. 2, pp. 1-10, 2021.

[4] Checa I., Rocio B., "Dyadic interaction in sports dance: psychological characteristics," 2019. DOI: 10.5093/rpaedf 2019a15

[5] Eka Fitri Novita Sari, Rekha Ratri Julianti, Nofi Marlina Siregar, Sukiri, "Locomotor Basic Movement Levels in Improving the Health of Elementary School Students," International Journal of Human Movement and Sports Sciences, 8(6A), pp. 16-21, 2020. DOI: 10.13189/saj.2020.080703.

[6] Guan, Y., Gong, Y. "Research on Sports Dancing to Healthy Development of College Students, Proceedings of the 2014 International Conference on Global Economy, Finance and Humanities Research," 2014. DOI: 10.2991/gefhr-14.2014.26

[7] Gumenyuk T., Palchynska M., Herchanivska P., Kozak Y., Kobyzhcha N., "Overcoming the modern socio-cultural crisis - From postmodern to post-postmodern: Theoretical aspects, " International Journal of Criminology and Sociology, Vol. 10, No. 8, pp. 745-752, 2021.

[8] Gusak Y., Vorona V., "Features of the use of sports dances in the field of physical culture and sports," Naukoviy chasopis NPU imeni M. P. Drahomanova, Vol. 1, no. 129, pp. 27-31, 2021. DOI: 10.31392/NPU-nc.series15.2021.1( 129).06

[9] Karyy O., Knjazevska O., "Tasks prioritization of strategic planning of cities development: Experts' approach," Economics and Sociology, Vol. 2, No. 1, pp. 58-66, 2009.

[10] Katarinčić I., "Paradoxes of sport dance," Etnoloska Tribina, Vol. 42, No. 35, pp. 207-224, 2012.

[11] Linda N. Chukwurah, Oliver I. Abbah, Cylia N. Iweama, John E. Ogugua, Jonathan Ameh. Students' Achievement in Physical and Health Education: Effect of Discussion Teaching Method. International Journal of Human Movement and Sports Sciences, 8(3), pp. 86-90, 2020. DOI: 10.13189/saj.2020.080302.

[12] Nur Cholis Majid, Fauzi, "The Effect of Sprint Training on Vertical Jump Height of Female Youth Volleyball Players," International Journal of Human Movement and Sports Sciences, Vol. 9, No. 2, pp. 334-339, 2021. DOI: 
10.13189/saj.2021.090222.

[13] Omelyanenko V., "Dynamic meditation in sports dances," Pedagogics Psychology Medical-biological Problems of Physical Training and Sports, Vol. 1, 2014. DOI: $10.6084 / \mathrm{m} 9$.figshare. 894390

[14] Poplavskyi M., "Entrepreneurship in the field of art business in the European union," Journal of Entrepreneurship Education, Vol. 22, No. 6, 2019.
[15] Raiola G., "Inclusion in sport dance and self perception," Sport Science, Vol. 8, pp. 99-102, 2015.

[16] Shan H., Liu Y., "Feature recognition of body dance motion in sports dancing," Metallurgical and Mining Industry, Vol. 7, No. 7, pp. 290-297, 2019.

[17] Wilmore J., Costill D., "Physiology of sport and exercise," Champaign Publishing, 3rd ed, 2004, 744 p. 